\title{
Does Financial Literacy Influencing the University Student's Decision to Use M-Payment?
}

\author{
Amalina Maryam Zakiyyah ${ }^{1}$, Amri Gunasti², Isti Fadah ${ }^{3}$ \\ \{amalinamaryam@unmuhjember.ac.id ${ }^{1}$, amrigunasti@unmuhjember.ac.id ${ }^{2}$, istifadah1966@gmail.com ${ }^{3}$ \} \\ Universitas Muhammadiyah Jember ${ }^{1,2}$, Universitas Jember ${ }^{3}$
}

\begin{abstract}
Based on the annual data released by We are Social 2020, shows that Indonesia is a country with the highest rate of e-commerce adoption in the world, but is lagging behind in using mobile payments (m-payment). However, it is common to find that m-payment integrated with e-commerce. Why does it happen? To find this out, we conducted this research. The Technology Acceptance Model (TAM) used to parse the decision to use the m-payment technology. Then added financial literacy as antecedent for decision using $\mathrm{m}$ payment. Data collected using questionnaires distributed to students and collected 120 respondents, then analyzed by using SEM. The result showed that the perception of easy to use is not a consideration in using m-payment but rather the perception of usefulness and security. The financial literacy does not influence the intention to use m-payment, but it has an impact on the behavior of using $\mathrm{m}$ payment.
\end{abstract}

Keywords: mobilepayment, perceived of trust financial literacy, TAM, intention to use, usage behavior

\section{Introduction}

Internet technology has been considered as one of the instruments accelerating a country's economic growth [1]. Because through the internet many opportunities can be created, many inventions are innovated, many works and knowledge are distributed. The internet makes it easier for economic transactions and the production, consumption and distribution of products and services.

According to data released by Hootsuit in collaboration with, We are Social, there were 175.4 million internet users in Indonesia in January 2020. The number has increased by 17 percent or equivalent to 25 million new users recorded from the previous year [2].

The growth of financial technology as one of the impacts from the development of internet technology in Indonesia. Financial technology 
according to Bank Indonesia is the application of technology in the financial system which produces derivative products in the form of new products, services, technology and / or business models [3]. The development of financial technology has benefits for consumers, businesses, and the national economy, especially in terms of efficiency, continuity, security, and reliability of the payment system.

Another impact of the development of the internet is the existence of ecommerce. E-commerce is the activity of buying and selling goods and or services, or the transmission of funds or data through electronic networks, especially the internet. With the development of information technology and software, this has made conventional transactions possible electronically [4].

We Are Social states that Indonesia is a country with the highest level of ecommerce adoption (use) in the world [5]. The data shows 88 percent of the total number of internet users in Indonesia. This indicates that approximately 8 out of 10 internet users in Indonesia have made online purchases [6].

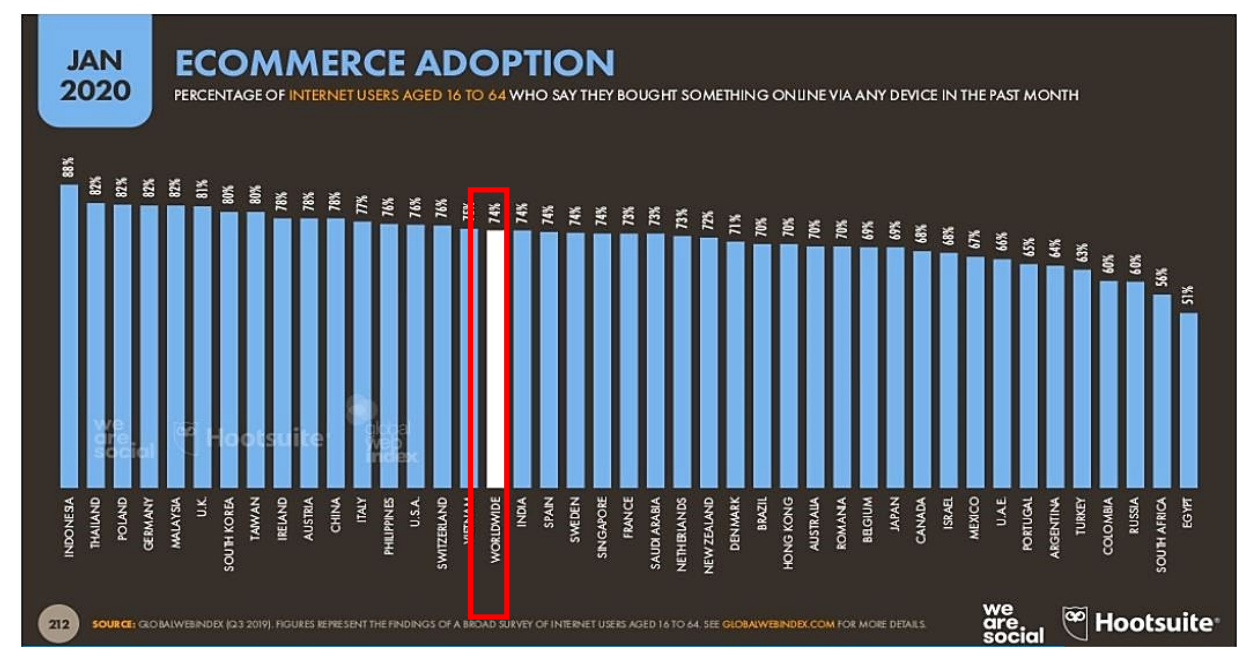

Fig. 1. Ecommerce Adoption Statistic

However, according to We Are Social data, Indonesia is still far behind in the use of financial technology in both banking and other financial facilities. Even still lower than the global average which is indeed low, namely only 33 percent of total internet users who use it [5], [6]. Then mobile payment users as the payment for e-commerce transactions only 24 percent of the internet users. This is contradictory considering the high internet users and the level of ecommerce usage in Indonesia, apparently has not been able to boost the level of financial technology adoption, especially mobile payment. 


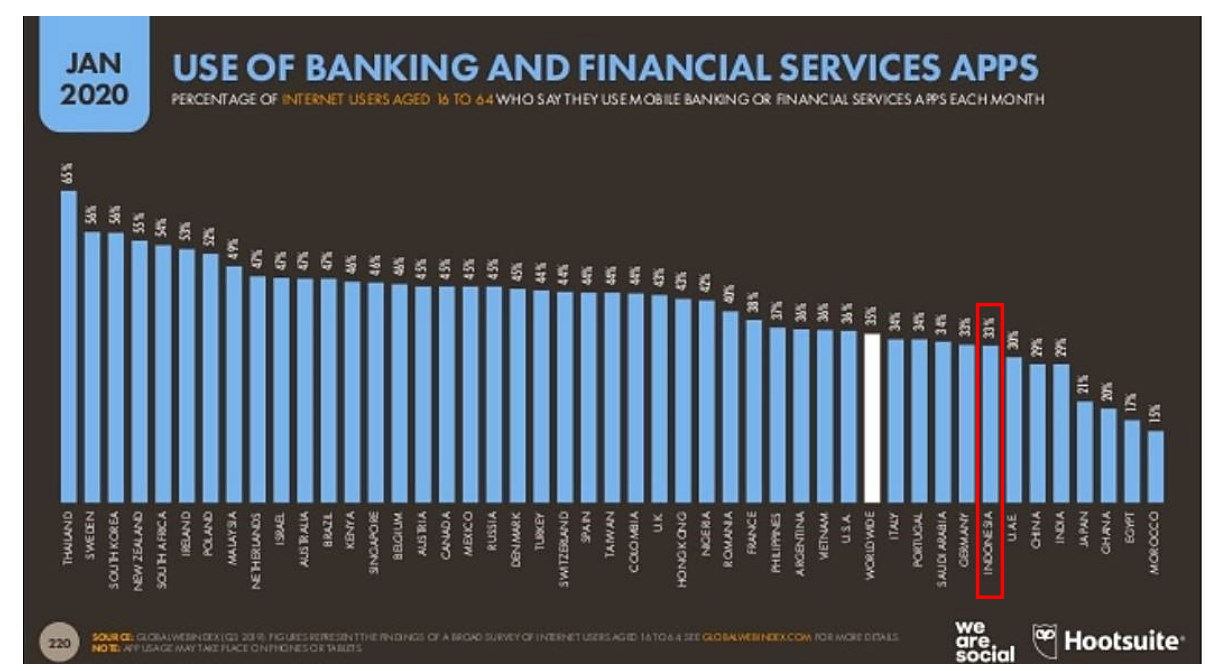

Fig. 2. Use of Banking and Financial Services Apps Statistic

The high level of internet penetration in Indonesia, which has an impact on the high rate of adoption of e-commerce, but not accompanied by the use of financial services and online banking, raises a question mark for academics and practitioners. Therefore, the purpose of this study is to analyze the level of mobile payment acceptance as one part of financial technology integrated with e-commerce.

The current development of banking and financial services is an advanced development with technology. Although the level of financial inclusion in Indonesia is increasing, financial technology has not yet been adopted. One of them is the mode of payment through cellular networks, namely m-payment. Chandra et al. Identified that there are several reasons for the low adoption rate due to the limited attributes of the mobile device and network, the low maturity level of the m-payment solution, limited advantages over other modes of payment, and existing consumer behavior change requirements [7]

The most often model used to determine acceptance of technology is the Technology Acceptance Model (TAM). In its origin model, TAM states that perceived usefulness (PU) and perceived ease of use (PEOU) of the new technology are related to the intention of the consumers to use it (ITU), and finally affect the actual use of the technology (UB) [8], [9].

Over time, the model develops. Some of the researchers offer to add security perceptions as an independent variable of the intention to use e-payment systems [10], [11], [12]. Perception of trust [13], [7], [14]. In another study, 
adding attitude variables toward using mobile payment [15], [16] and perceptions about risks [11], [17].

In the 2020 Indonesia Financial Services Authority report on the development of financial technology, announced that the majority of lenders and borrowers are in the age of 19-34 years old [18]. So, the millennial generation is the most active age group in accessing this facility, can say that.

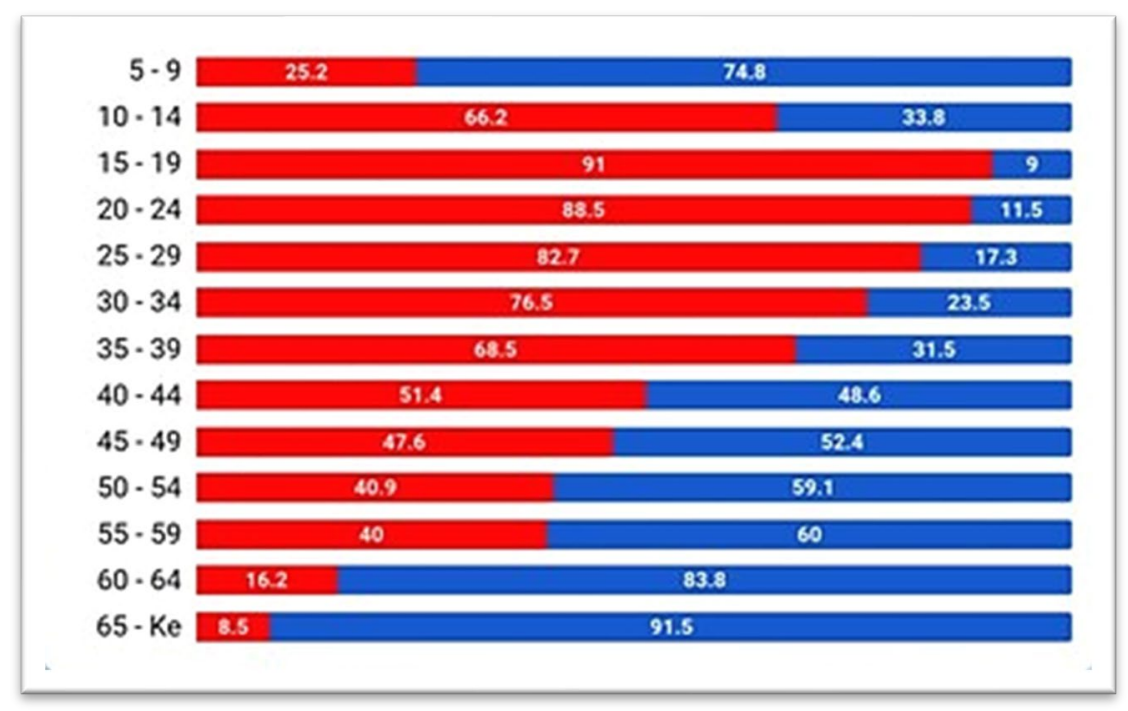

Fig. 3. Internet User Based on Age

Then based on survey data revealed by the Indonesian Internet Service Providers Association (APJII), in terms of age, internet users are mostly in the age group of 15-34 years old or better known as the millennial age group. A millennial is a group of people who were born in the early 1980s to early 2000 s [19].

From the results of a survey released by APJII, it identified that based on the level of education, the highest internet users are in higher education both who have not completed college or currently studying diploma, S1, S2, and S3 [19]. However, do these internet users in their young adults and high education have a proper level of financial literacy?

Why is financial literacy necessary?

Financial literacy is considered the knowledge and ability of personal financial management. Without the knowledge of financial concepts, a person will not be able to make the right financial decisions, such as decisions regarding saving, investing, borrowing, and more [20], [21]. A number of studies have 
found that a higher level of financial knowledge is often associated with better financial behavior, which in turn contributes to welfare improvement [22].

Previous studies found that students with less financial management knowledge tend to make incorrect financial decisions [23], but improving significantly every year [22]. In contrast to previous studies, a good level of financial literacy does not always have implications for good financial decision making [24]. The survey results show an increase in financial literacy in Indonesia, but still below than Malaysia and Singapore [25]. The development of the internet contributed to the improvement of financial literacy [26], [27].

\section{Literature Reviews}

\subsection{Technology Acceptance Model}

TAM has been used extensively to study IT adoption behavior and is considered to be the basic theory for technology acceptance and adoption [9]. This model predicts factors that influence the level of acceptance and use of new technology (28). TAM is a model built based on the Theory of Reasoned Action (TRA) [29]. TRA asserts that the most important determinant of behavior is behavioral intention. Moderate individual behavioral intentions are influenced by attitudes and subjective norms of users towards the behavior of the target behavior.

According to this model, users decide to use a new technology or information system preceded by an intention to use it. This intention is influenced by the perceived usefulness and perceived ease of use. The basic model states that the perceived usefulness (PU) and perceived ease of use (PEOU) of new technology are related to the behavioral intention to use IS, and finally to the actual use of IS [9], [30].

Davis (1989) defines 'perceived ease of use' as the level of user confidence that using new technology will be free of effort, or new technology is easy to use. Previous research has shown that PEOU has a positive effect on ITU [31], [32], [33], [34]. Meanwhile, [35] and [28] did not find evidence that PEOU influenced ITU.

Whereas 'perceived usefulness' is defined as the rate at which users believe that using the system will improve their job performance (e.g. Is using this tool useful for my daily life tasks?) [30]. PU has a positive effect on behavioral intention to use new technology [28], [32], [33]. However, [35] and [34] found no evidence that $\mathrm{PU}$ has a positive effect on behavioral intention to use new technology. 
Over time, the model develops. Some researchers offer to add security perceptions as an independent variable of the intention to use e-payment systems [10], [11], [12]. Perception of trust [7], [11], [14]. In another study adding attitude variables toward using mobile payment [15], [16] and perceptions about risks [11], [17].

Recognizing as an essential factor influencing adoption for online transactions, especially for monetary transactions, the perceived trust [7], hence data privacy is the key-factor of security features expected from each $\mathrm{m}$ payment procedure [36].

In this article, the researcher will use the basic model of TAM, namely perceived ease of use and perceived usefulness that will be antecedent from the intention to use m-payment. Then we add the perceived trust in the model.

H1: University students' perceived ease of use of the m-payment has a positive effect on his or her intention to use m-payment

$H 2$ : University students' perceived usefulness of the m-payment is positively affecting his or her intention to use m-payment

H3: University students' perceived the trust of the m-payment is positively affecting his or her intention to use m-payment

\subsection{Financial Literacy:}

Financial literacy is the ability of people to process economic information and make decisions based on that information regarding financial planning, wealth accumulation, debt, and pensions [20].

Financial literacy is considered to be the knowledge and ability of personal financial management. Without the knowledge of financial concepts, a person will not be able to make financial decisions, such as decisions regarding saving, investing, borrowing, and more [20], [21]. A number of studies have found that a higher level of financial knowledge is often associated with better financial behavior, which in turn contributes to welfare improvement [22].

The level of financial literacy needs to be tested, measured, and evaluated, especially the level of students studying economics, to know the extent to which education related to financial literacy has been successfully applied and affects the future of our society and well-being [37].

Previous research finds that students with less knowledge about financial management tend to make wrong financial decisions [22], [23], but it significantly improved each year [38]. In contrast to previous studies, a good level of financial literacy does not always have implications for good financial decision making [24]. The survey results indicate an increase financial literacy in Indonesia, but it is still below the neighboring countries like Malaysia and 
Singapore [25]. The development of the internet contributed to increased financial literacy [26], [27].

H4: University students' financial literacy is positively affecting his intention to use m-payment

H5: University students' financial literacy is positively affecting his or her usage behavior of m-payment

H6: University students' intention to use m-payment is positively affecting his or her usage behavior of m-payment

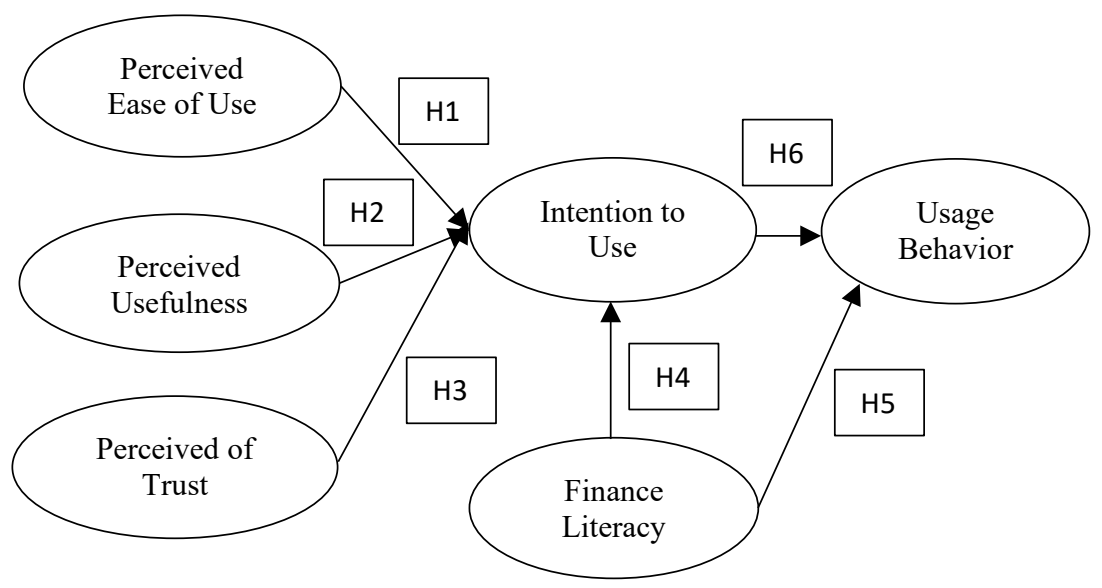

Fig. 4. Framework

\section{Methods}

This type of research is explanative because it aims to test the hypotheses that have been built from the TAM model. The built framework appears in fig. 4 presents the hypothesis that connects the variables to be studied. It is expected that the model that has been built can measure the ability of PEOU, PU, PT, and student financial literacy as predictor variables for students' intention to use and behavior in using m-payment.

The population we studied was students at three tertiary institutions in Jember Regency, namely the University of Jember, University of Muhammadiyah Jember, and Poltek Jember. We took samples using a sampling technique that was convenient sampling. Finally, it reached the number of 
respondents as many as 120 students who became respondents in this study (details can be seen in Table 1).

The data used are primary data, which means that data is collected directly from respondents. The data collection method is through a questionnaire.

The questionnaire distributed consists of 2 major parts, of which the first part is a model of TAM and the second part is about financial literacy which is divided into 2 subsections namely Basic Financial Literacy and Advanced Financial Literacy based on the constructs of Lusardi and Mitchell [20]. The awarding of points is based on the rules, namely 1 for the answer you don't know, 2 for the wrong answer, and 3 for the right answer.

Apart from the financial literacy variables, all are latent variables that require indicators. Measurement of latent variables (exogenous and endogenous variables) was carried out with a Likert scale of 1-5 where 1 for strongly disagree and 5 for strongly agree.

The perceived ease of use (PEOU) variable is the user's perception that $\mathrm{m}$ payment is easy to use, does not require excessive effort, and is easy to become an expert in its use [39]. Perceived Usefulness (PU) is the user's perception that m-payment improves user performance, makes transactions easier, and completes faster [17]. Perceived of Trust (PT) is the user's trust in the mpayment system [7] which means that believing that user data is safe, user's financial data is safe, and payments with vendors are carried out [13].

Endogenous variables in this study are ITU and Usage Behavior. Intention to Use (ITU) is the respondent's intention to use m-payment. Apart from that, it is also the respondent's intention to recommend an m-payment. As well as the respondent's opinion that using m-payment is a pleasant experience [34]. And Usage Behavior is the respondent's response to the behavior of using $\mathrm{m}$ payment. Measurements were made on a Likert scale of 1-5 where 1 for strongly disagree and 5 for strongly agree. Furthermore, the data were analyzed using the Structural Equation Model (SEM) through the AMOS statistical application.

\section{Results}

\subsection{Demographic Profile}

\begin{tabular}{|l|c|c|}
\hline Gender & Total & Percentages \\
\hline Male & 33 & $27.5 \%$ \\
\hline Female & 87 & $72.5 \%$ \\
\hline Campus & & \\
\hline
\end{tabular}




\begin{tabular}{|l|c|c|}
\hline Universitas Jember & 34 & $28.3 \%$ \\
\hline $\begin{array}{l}\text { Universitas Muhammadiyah } \\
\text { Jember }\end{array}$ & 28 & $23.3 \%$ \\
\hline Politeknik Negeri Jember & 58 & $48.3 \%$ \\
\hline Major Faculty & & \\
\hline Economic and Business & 22 & $18.3 \%$ \\
\hline Computer & 20 & $16.7 \%$ \\
\hline Health & 59 & $49.2 \%$ \\
\hline Education & 13 & $10.8 \%$ \\
\hline Social & 6 & $5.0 \%$ \\
\hline Semester & & \\
\hline 2 & 15 & $12.5 \%$ \\
\hline 4 & 75 & $62.5 \%$ \\
\hline 6 & 10 & $8.3 \%$ \\
\hline 8 & 17 & $14.2 \%$ \\
\hline 10 & 3 & $2.5 \%$ \\
\hline Consumption & & \\
\hline Around Rp 30.000 per day & 95 & $79.2 \%$ \\
\hline Around Rp 60.000 per day & 16 & $13.3 \%$ \\
\hline Around Rp 100.000 per day & 5 & $4.2 \%$ \\
\hline Around Rp 150.000 per day & 4 & $3.3 \%$ \\
\hline
\end{tabular}

The table above provided information about the description of the respondents or the demographic conditions of the respondents. It is known that the majority of female respondents $(87 \%)$ were in semester 4 or second year $(75 \%)$ of the health major (59\%) in the Politeknik Negeri Jember (58\%) with a daily consumption value of around $\mathrm{Rp} 30,000$ per day (95\%).

Table 2. Validity Reliability Tests

\begin{tabular}{lcc}
\hline \multicolumn{1}{c}{ Variables } & CR & AVE \\
\hline Perceived Easy of Use (39) (34) & 0.922 & 0.799 \\
\hline Perceived of Usefulness (17) (34) & 0.910 & 0.773 \\
\hline Perceived of Trust (7) (13) & 0.873 & 0.696 \\
\hline Intention to Use (34) & 0.858 & 0.668 \\
\hline Actual Usage (Usage Behavior) & 0.757 & 0.757 \\
\hline
\end{tabular}




\begin{tabular}{lll}
\hline Financial Literacy (40) & 0.868 & 0.366
\end{tabular}

\subsection{Validity and Reliability Test}

Table 3. Validity and Reliability Test Results After Modification

\begin{tabular}{ccccccc}
\hline Variable & Indicators & $\boldsymbol{\lambda}$ & $\boldsymbol{\lambda}^{\mathbf{2}}$ & $\mathbf{e}$ & CR & AVE \\
\hline \multirow{6}{*}{ FL } & FL2A & 0,5 & 0,250 & 0,750 & & \\
\cline { 2 - 5 } & FL2B & 0,71 & 0,504 & 0,496 & & \\
\cline { 2 - 5 } & FL2C & 0,51 & 0,260 & 0,740 & & \\
\cline { 2 - 5 } & FL2D & 0,78 & 0,608 & 0,392 & 0,867 & \multirow{2}{*}{0,501} \\
\cline { 2 - 5 } & FL2E & 0,75 & 0,563 & 0,438 & & \\
\cline { 2 - 5 } & FL2F & 0,87 & 0,757 & 0,243 & & \\
\cline { 2 - 5 } & FL2H & 0,70 & 0,490 & 0,510 & & \\
\hline
\end{tabular}

Tables 2 and 3 showed a description analysis of the data collected from 120 respondents. The data were tested for the validity and reliability of the instrument. Based on the table above all variables have $C R$ values greater than 0.7 so it can be concluded that all variables are reliable. Then most of the indicators have a loading factor $(\lambda)$ value greater than 0.5 except for 3 indicators for the financial literacy variables. All variables other than financial literacy are considered valid. Therefore, the financial literacy variables were valid, then 3 indicators with a loading factor of less than 0.5 are deleted (shown in table 3 ).

Table 4. Level of Financial Literacy Respondents

$\begin{array}{ccc} & \text { BASIC } & \text { ADVANCED } \\ \text { CRITERIA } & \text { FINANCIAL } & \text { FINANCIAL } \\ & \text { LITERACY } & \text { LITERACY }\end{array}$

\begin{tabular}{l|rrrr} 
Well Literate & 10 & $8 \%$ & 10 & $8 \%$ \\
Sufficient Literate & 26 & $22 \%$ & 16 & $13 \%$ \\
Less Literate & 35 & $29 \%$ & 34 & $28 \%$ \\
Not Literate & 49 & $41 \%$ & 60 & $50 \%$ \\
& & $100 \%$ & & $100 \%$
\end{tabular}

The level of financial literacy of respondents that is included in the well literate criteria both at the level of basic financial literacy and advanced financial literacy was only $8 \%$. From 120 respondents there were only 10 people who 
have an understanding and trust in financial institutions, financial products and services and have the ability to make financial decisions in using financial products and services. Whereas in the criteria of sufficient literate and less literate, each level does not differ much by around $20 \%$ from 120 respondents. Moreover, $40 \%-50 \%$ of respondents are most in the criteria of not literate. Not literate respondents are considered to not having an understanding or trust in financial services institutions, financial products and services, also not having skills in using financial products and services [41].

\subsection{Model Fit Test}

Evaluation of the Goodness of Fit criteria is an evaluation of the feasibility test of a model with some criteria for suitability of the index and its cut-off value, in order to state whether a model can be accepted or rejected [42].

Table 5. Goodness of Fit Test

\begin{tabular}{|c|c|c|c|c|c|}
\hline \multirow{3}{*}{$\begin{array}{c}\text { MEASURE } \\
\text { OF FIT } \\
\text { MODEL } \\
\text { CHI-SQUARE }\end{array}$} & \multirow[t]{3}{*}{ STANDARD } & \multicolumn{2}{|c|}{$\begin{array}{c}\text { BEFORE } \\
\text { MODIFICATION }\end{array}$} & \multicolumn{2}{|c|}{$\begin{array}{c}\text { AFTER } \\
\text { MODIFICATION }\end{array}$} \\
\hline & & Results & Fit Index & Results & Fit Index \\
\hline & & 237,58 & & & \\
\hline $\begin{array}{c}\text { SIG. } \\
\text { PROBABILITY }\end{array}$ & $\geq 0,05$ & 0,00 & Bad fit & 0,15 & Good fit \\
\hline RMSEA & $\leq 0,08$ & 0,06 & Good fit & 0,03 & Good fit \\
\hline NFI & $\geq 0,90$ & 0,87 & Marginal fit & 0,90 & Good fit \\
\hline CFI & $\geq 0,90$ & 0,95 & Good fit & 0,99 & Good fit \\
\hline IFI & $\geq 0,90$ & 0,95 & Good fit & 0,99 & Good fit \\
\hline RFI & $\geq 0,90$ & 0,72 & Marginal fit & 0,89 & Marginal fit \\
\hline RMR & $\leq 0,05$ & 0,04 & Good fit & 0,06 & Good fit \\
\hline GFI & $\geq 0,90$ & 0,83 & Marginal fit & 0,87 & Marginal fit \\
\hline AGFI & $\begin{array}{c}0,80 \leq \mathrm{AGFI}< \\
0,90\end{array}$ & 0,78 & Bad fit & 0,82 & Good fit \\
\hline
\end{tabular}

Based on the table of the testing the suitability results of the model above, noted that the value of sig. probability and AGFI are in bad fit suitability. Then the NFI, RFI and GFI indicators were still at the marginal fit, so it needs to be modified. After the modification, there were only two indicators that are at marginal fit and it can be said that the model has met the minimum requirements and can be tested hypotheses [42]. 


\subsection{Hypothesis Test}

Table 6. Hypothesis Tests

\begin{tabular}{|c|c|c|c|c|c|}
\hline Hypothesis & Estimate & S.E. & C.R. & $\mathbf{P}$ & Sig. \\
\hline ITU <--- PEOU & $-0,205$ & 0,183 & $-1,120$ & 0,263 & Not significant \\
\hline ITU <--- PU & 0,446 & 0,184 & 2,425 & 0,015 & Significant \\
\hline ITU <--- PT & 0,578 & 0,087 & 6,625 & $* * *$ & Significant \\
\hline ITU <--- FL & $-0,053$ & 0,083 &,- 641 & 0,521 & Not significant \\
\hline UB <--- ITU & 1,105 & 0,152 & 7,258 & $* * *$ & Significant \\
\hline UB <--- FL & 0,306 & 0,163 & 1,880 & 0,060 & Not significant \\
\hline
\end{tabular}

Table 6 hypothesis testing shows that PEOU and FL have a negative and insignificant effect on ITU, which means $\mathrm{H} 1$ and $\mathrm{H} 4$ are rejected. PU and PT have a significant positive effect on ITU so that $\mathrm{H} 2$ and $\mathrm{H} 3$ are accepted. Then ITU and FL are proven to have a significant positive effect and it can be concluded that H5 and H6 are accepted.

\section{Discussion}

The Perceived Easy of Use has no significant negative effect on students' desire to use the m-payment. Although it has a negative influence, which means that the more increase in the easiness of using m-payment, the more reluctance for the students to use it, but the effect is not significant.

Technology has shifted its role, which previously only became an alternative, but now has moved to become the central player. The application of information technology in almost every life aspects forces end users to become familiar with the digital world and all online. Consequently, the perception of convenience has no longer been in use into consideration in the process of technology adoption.

These results differed from the basic idea of the technology acceptance model by Davis, 1989 [8], that the perception of ease of use is one of the fundamental determinants of user acceptance [14], [15], [17], [34]. However, this finding is in line with the results of a research by Gefen and Straub [30], wherein the perception of convenience is not directly related to the intention of technology adoption. 
The perception of usefulness has a significant positive effect on the students' desire to use m-payment. Even before becoming an m-payment user or while becoming a temporary user, respondents have experienced that using m-payment makes transactions at ease and increases their performance, thereby increases the desire to use m-payment. This result is consistent with previous research. So, validated that the perceived usefulness affects the intention to use new technology.

In the condition of the Covid-19 pandemic which requires everyone to reduce activities outside the home and make cashless transactions, making $\mathrm{m}$ payment as a smart solution for transactions. The government even recommended reducing the use of cash, which is considered as one of the media to spread the virus.

Security and trust issues are still proven a driving factor for using $\mathrm{m}$ payment. The results show that the perception of trust has a positive and significant influence on the desire to use. The results of this study are in line with previous findings that perceived security and trust issues are determinants factor in the intention to adopt m-payment [7], [36]. Respondents assume that m-payment nowadays offers security to adjust to what users expected compared to the cash payment mode. Perceived security and trust offered indicates that the m-payment service provider is always trying to improve its services. On the other hand, the massive cashless campaign is encouraged to educate respondents that m-payment is safer than cash.

The level of students' financial literacy was found to have an insignificant negative effect on students' willingness to use m-payment. Due to insignificant results, the high or low level of financial literacy of a student does not determine students to have the desire to take advantage of m-payment. The results found that $40 \%$ of respondents did not have basic financial literacy and $50 \%$ did not have advanced financial literacy, but apparently had the desire to use mpayment that was quite high, mean 3.76 on a Likert scale 5. Therefore, knowledge, understanding, and skills in financial matters have no impact on respondents' desire to use m-payment. Therefore, it has not been taken into consideration in the respondents' process of decision making in technology adoption.

The students' intentions or desires have a stake in shaping student decisions in using m-payment. The intention to use m-payment positively and significantly influences the decision to use m-payment. This result support the Theory Reasoned Action (TRA), which is the grand theory of TAM, that states the determinant of behavior is behavioral intention. So, the decision to use $\mathrm{m}$ payment occured because of the intention or desire of the respondent [8], [29]. 
Although many TAM studies only aiming to determine the determinant of intention [7], [17], [39], [43].

The level of student financial literacy has a positive influence on the decision to use m-payment, but no significant effect. Financial literacy is a factor in the use of m-payments. The result is consistent that the desire to use $\mathrm{m}$-payment arisen because it has been considered safer than cash payment. The respondents' literacy level influenced their intents.

It means that the higher the level of financial literacy, the better one will make decisions, including the decision to use m-payment. These results are consistent with previous research, which found that a lack of knowledge about financial management causes risky financial behavior [22], [23], [44].

From the above results, financial literacy does not affect behavioral intention to use m-payments but has a significant effect on the usage behavior of m-payment. This is a contradictory result and is interesting to discuss. Financial literacy is a determinant variable for the decision to use m-payment but not a determinant variable for the intention to use. Intention to use is antecedent to the decision to use. So if financial literacy not a determinant for intention to use so nor the decision to use it. But the respondents seem only considering financial literacy when deciding on using new technology, not in shaping intention.

\section{Conclusion, Limitations, and Suggestion}

Due to the Covid-19 pandemic, there are large-scale social restrictions (PSBB), and we collected the data on it. PSBB objective is to reduce activities outside the home and prohibit crowding activities to break the chain of spreading of the virus. This condition forces everyone without exception to reduce interactions include transactions, so m-payment is a reasonable solution.

The hypothesis that was developed in the study partly became rejected due to this unusual condition. It rejected the effect perceived ease of use of the students on the intention to use m-payment. It also rejected the impact of students' financial literacy on the intention to use m-payment.

Perceived ease of use and financial literacy did not influence intention to use m-payments, because two variables have shifted to no longer be determinant intentions. Although the new technology of m-payment is hard to use does not become something yet, because of the perceived usefulness and trust much greater than the difficulties.

Literacy level as the knowledge that is a determinant factor in TRA does not apply under these conditions too. Despite the lack of financial literacy, they still 
have the intention to use it. Perceived security and trust proved to be a determining factor in the intention to use m-payment because the perceived usefulness can guarantee the safety of the user.

Perceived of usefulness and trust remain as determinant factors of intention to use m-payment. The respondents have no other choices than using mpayment due to pandemic, besides they feel the benefit and safety in m-payment more than cash payment mode.

There are both limitations and excellence that could be found in this paper. Limit because of the results of this study cannot be generalized under normal conditions. Another limit in this study, the control variables of the respondents' demographics have not been analyzed yet. But it is also an advantage because this research is one of the TAM studies in unusual conditions.

Suggestions for further research are to identify the elements of perceived usefulness better in the context of m-payment; to examine two quality factors that are most valuable in the payment industry: transaction speed and convenience. The real-time transactions speed is very supportive in improving performance and influencing perceptions of the benefits of m-payment. A platform that cannot guarantee transaction speed will lose its appeal. Convenience in the transaction is things to be expected because the main advantage of $\mathrm{m}$-payment is the ease of making payments in one way.

\section{References}

[1] Kontan. Internet memacu pertumbuhan ekonomi sebesar 1,25\% [Internet]. nasional.kontan.co.id. 2014 [cited 2020 Jul 23]. p. Kebijakan. Available from: https://nasional.kontan.co.id/news/melalui-internetpacu-pertumbuhan-ekonomi-125

[2] We are social. Digital 2020: Indonesia - DataReportal - Global Digital Insights [Internet]. 2020 [cited 2020 Apr 25]. Available from: https://datareportal.com/reports/digital-2020-indonesia

[3] Bank Indonesia. Teknologi Finansial - Bank Sentral Republik Indonesia [Internet]. bi.go.id. 2017 [cited 2020 Jul 23]. Available from: https://www.bi.go.id/id/sistempembayaran/fintech/Contents/default.aspx

[4] Rouse M. What is e-commerce (electronic commerce)? - Definition from WhatIs.com [Internet]. searchcoi.techtarget.com. [cited $2020 \mathrm{Jul}$ 23]. Available from: https://searchcio.techtarget.com/definition/e- 
commerce

[5] Hootsuite, We are social. Digital 2020: what you really need to know We Are Social Singapore [Internet]. 2020 [cited 2020 Apr 25].

Available from: https://wearesocial.com/sg/blog/2020/01/digital-2020what-you-really-need-to-know

[6] Ramadhan B. Data Internet di Indonesia dan Perilakunya Tahun 2020 [Internet]. teknoia.com. 2020 [cited 2020 Apr 25]. Available from: https://teknoia.com/data-internet-di-indonesia-dan-perilakunya$880 \mathrm{c} 7 \mathrm{bc} 7 \mathrm{~cd} 19$

[7] Chandra S, Srivastava SC, Theng Y-L. Evaluating the Role of Trust in Consumer Adoption of Mobile Payment Systems: An Empirical Analysis. Commun Assoc Inf Syst. 2018;

[8] Davis FD. Perceived usefulness, perceived ease of use, and user acceptance of information technology. MIS Q Manag Inf Syst. 1989 Sep;13(3):319-39.

[9] Lippert SK. Investigating postadoption utilization: An examination into the role of interorganizational and technology trust. IEEE Trans Eng Manag. 2007 Aug;54(3):468-83.

[10] Junadi, Sfenrianto. A Model of Factors Influencing Consumer's Intention to Use E-payment System in Indonesia. In: Procedia Computer Science. 2015. p. 214-20.

[11] Yang Y, Liu Y, Li H, Yu B. Understanding perceived risks in mobile payment acceptance. Ind Manag Data Syst. 2015;

[12] Johnson VL, Kiser A, Washington R, Torres R. Limitations to the rapid adoption of M-payment services: Understanding the impact of privacy risk on M-Payment services. Comput Human Behav. 2018;

[13] Yang Q, Pang C, Liu L, Yen DC, Michael Tarn J. Exploring consumer perceived risk and trust for online payments: An empirical study in China's younger generation. Comput Human Behav. 2015;50:9-24.

[14] Anthony D, Mutalemwa D. Factors influencing the Use of Mobile Payments in Tanzania : Insights from Zantel's Z-pesa Service. J Lang Technol Entrep Africa. 2014;5(2):69-90.

[15] Sasithanakornkaew S, Phokiew N, Poonpermpong P, Bumrungrat V, Udomsinkha N, Srisang-on W. Acceptance of Qr Code Payment Technology in Mobile Banking Applications Among Kasetsart 
University'S Students 1 Saranthorn Sasithanakornkaew, 2 Navarat Phokiew, 3 Pantakorn Poonpermpong, 4 Valenrudee Bumrungrat, 5 Narisara Udomsinkha, 6 Waritsara Srisang-. In: Proceeding of 124th IASTEM Internatonal COnference [Internet]. Krakow, Poland; 2018. p. 7-9. Available from:

http://www.worldresearchlibrary.org/up_proc/pdf/1760-153551952679.pdf

[16] Amalia SNA. Faktor-Faktor Yang Mempengaruhi Minat Individu Terhadap Financial Technology (Fintech) Syariah (Paytren) Sebagai Salah Satu Alat Transaksi Pembayaran (PendekatanTechnology Acceptance Model (TAM) dan Theory Of Planned Behavior (TPB). Iqtishaduna [Internet]. 2018;8(1):57-73. Available from: http://journal.uinmataram.ac.id/index.php/iqtishaduna/article/view/687

[17] Chen L da. A model of consumer acceptance of mobile payment. Int J Mob Commun [Internet]. 2007 [cited 2019 May 30];6(1):32. Available from: http://www.inderscience.com/link.php?id=15997

[18] OJK. Perkembangan Fintech Lending. 2020.

[19] APJII. Penetrasi \& Profil Perilaku Pengguna Internet Indonesia Tahun 2018 [Internet]. APJII: Laporan Survei. 2019. Available from: www.apjii.or.id

[20] Lusardi A, Mitchell OS. The economic importance of financial literacy: Theory and evidence. J Econ Lit. 2014;52(1):5-44.

[21] Potrich ACG, Vieira KM, Kirch G. How well do women do when it comes to financial literacy? Proposition of an indicator and analysis of gender differences. J Behav Exp Financ [Internet]. 2018;17:28-41. Available from: https://doi.org/10.1016/j.jbef.2017.12.005

[22] Xiao JJ, Ahn SY, Serido J, Shim S. Earlier financial literacy and later financial behaviour of college students. Int J Consum Stud. 2014 Nov 1;38(6):593-601.

[23] Chen H, Volpe RP. An analysis of personal financial literacy among college students. Financ Serv Rev. 1998 Jan 1;7(2):107-28.

[24] Fitriarianti B. PENGARUH LITERASI KEUANGAN, PERILAKU KEUANGAN DAN PENDAPATAN TERHADAP KEPUTUSAN BERINVESTASI [Internet]. Vol. 1, PROSEDING SEMINAR NASIONAL AKUNTANSI. 2018 Feb [cited 2020 Jul 24]. Available from: http://openjournal.unpam.ac.id/index.php/SNU/article/view/941 
[25] Otoritas Jasa Keuangan. Siaran Pers Survei OJK 2019: Indeks Literasi Dan Inklusi Keuangan Meningkat. Sp 58/Dhms/Ojk/Xi/2019. 2019;(November): 1 .

[26] Alvara Reasearch Center. THE URBAN MIDDLE-CLASS MILLENIALS INDONESIA: Financial and Online Behavior [Internet]. 2017 [cited 2020 Mar 27]. Available from: www.alvara-strategic.com

[27] Ningtyas MN. Literasi Keuangan pada Generasi Milenial. J Ilm Bisnis dan Ekon Asia. 2019;13(1):20-7.

[28] Kustono AS, Nanggala AYA, Mas'ud I. Determinants of the Use of EWallet for Transaction Payment among College Students. J Econ Business, Account Ventur. 2020;23(1):85-95.

[29] Montaño DE. Health Behavior and Health Education: Theory, Research, and Practice. Ann Intern Med. 1992;116(4):350.

[30] Gefen D, Straub D. The Relative Importance of Perceived Ease of Use in IS Adoption: A Study of E-Commerce Adoption. J Assoc Inf Syst. 2000;1(1):1-30.

[31] Hatmawan AA. Analisis Niat Konsumen Menggunakan M Payment. Cap J Ekon dan Manaj. 2019 Sep 5;3(1):60.

[32] Shankar A, Datta B. Factors Affecting Mobile Payment Adoption Intention: An Indian Perspective. Glob Bus Rev. 2018 Jun 1;19(3_suppl):S72-89.

[33] Sumerta IK, Widyagoca IGPA, Adiandari AM, Herlambang PGD. Analysis of technology acceptance model (TAM) to use E-money in Bali Province. Int J Adv Trends Comput Sci Eng. 2019;8(1. 5 Special Issue):206-11.

[34] Rahayu FS, Budiyanto D, Palyama D. Analisis Penerimaan E-Learning Menggunakan Technology Acceptance Model (Tam) (Studi Kasus: Universitas Atma Jaya Yogyakarta). J Terap Teknol Inf. 2017;1(2):8798.

[35] Phonthanukitithaworn C, Sellitto C, Fong M. User intentions to adopt mobile payment services: A study of early adopters in Thailand. J Internet Bank Commer. 2015 Apr 1;20(1).

[36] Pousttchi K. CONDITIONS FOR ACCEPTANCE AND USAGE OF MOBILE. mBusiness. 2003;201-10.

[37] Josef N, Vera J. Financial Literacy And Behavioural Skills: The 
Influence Of Financial Literacy Level On Behavioural Skills. KnE Soc Sci [Internet]. 2017 Mar 19 [cited 2020 Apr 7];1(2):366. Available from: http://www.knepublishing.com/index.php/Kne-

Social/article/view/670/2027

[38] Jorgensen BL. College Student Financial Literacy Survey Welcome! Information and Consent Form. Virginia Tech; 2007 Oct.

[39] Park SY. An analysis of the technology acceptance model in understanding university students' behavioral intention to use elearning. J Educ Technol Soc. 2009;12(3):150-62.

[40] Lusardi A, Mitchell OS. How Ordinary Consumers Make Complex Economic Decisions: Financial Literacy and Retirement Readiness. Q J Financ. 2017 Sep 1;7(3).

[41] Andarsari PR, Ningtyas MN. The Role of Financial Literacy on Financial Behavior. JABE (JOURNAL Account Bus Educ. 2019 Sep $29 ; 4(1): 24$

[42] Ghozali I. Model Persamaan Struktural: Konsep dan Aplikasi dengan Program AMOS 22.0 Update Bayesian SEM. Semarang: Badan Penerbit Universitas Diponegoro. 2014.

[43] Park SY, Park SY. An Analysis of the Technology Acceptance Model in Understanding University... J Educ Technol Soc. 2009;12(3):150-62.

[44] Margaretha F, Pambudhi RA. TINGKAT LITERASI KEUANGAN PADA MAHASISWA S-1 FAKULTAS EKONOMI. J Manaj dan Kewirausahaan (Journal Manag Entrep. 2015 Mar 2;17(1):76-85. 